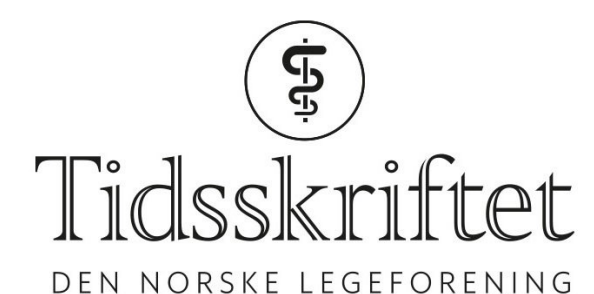

DEN NORSKE LEGEFORENING

\title{
Kjernetema i generell og akutt kirurgi
}

ANMELDELSER

KJETIL SøREIDE

Overlege, Gastrokirurgisk avdeling

Stavanger universitetssjukehus

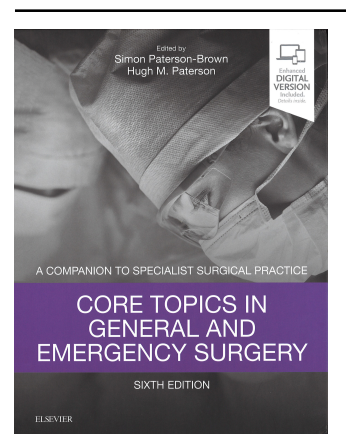

Simon Paterson-Brown, Hugh Paterson, red.

Core topics in general and emergency surgery

A companion to specialist surgical practice. 6. utg. 324 s, tab, ill. Edinburgh: Elsevier, 2018. EUR 98

ISBN 978-0-7020-7247-5

Denne boken er den første i en kjent serie av totalt 6 bøker som dekker de fleste av kirurgiske kjernefag. Hele serien foreligger nå i sin sjette utgave og kan således trygt nevnes som «klassikere» innen kirurgisk faglitteratur. Målgruppen er utdanningskandidater innen både generelle og spesialiserte kirurgiske fagfelt samt praktiserende kirurger. For dem som ikke kjenner konseptet: Disse bøkene skiller seg ut med relativt kortfattet tekst og tett fokus på kliniske anbefalinger støttet av aktuelle studier. Kapittel $1 \mathrm{i}$ boken omhandler vurdering av kirurgisk kunnskap og er en innledning til temaet ikke bare i denne, men også i de påfølgende spesialiserte bøkene (karkirurgi, lever-pancreaskirurgi, kolorektal kirurgi osv.).

Boken omtaler mange generelle tema, som perioperativ behandling og rekonvalesens (kapittel skrevet av prof. Kristoffer Lassen), organisering av akuttkirurgi, vurdering av kirurgisk risiko og ernæring av kirurgiske pasienter. Kapittelet Human factors and patient safety er nytt, tidsriktig og aktuelt - dette vil komme mer inn i kirurgenes utdanning og arbeidshverdag. Prinsipper for organdonasjon og transplantasjon er aktuelt for kirurger som kan bli involvert i donorsituasjon selv om de ikke jobber i et transplantasjonssenter. Andre kapitler er tematisk delt inn etter kjente tema: bukveggsbrokk, vurdering av akutt abdomen, sepsis, kunnskap om traume og halskirurgi for generellkirurger, akutte tilstander i øvre og nedre gastrointestinaltrakt (perforasjoner, blødninger, anorektale lidelser), lever-galle-pancreasfeltet (gallesteinssykdom, kolecystitter, pankreatitt), 
komplikasjoner etter fedmekirurgi eller akutte tilstander hos pasienter med overvekt. Enkelte akutte tilstander hos barn er også dekket.

Hvert kapittel avsluttes med en oppsummering av viktigste punkter. Kapitlene er rikt illustrert, viktige definisjoner eller kriterier er listet i tabeller eller bokser, og kjernepunkter er fremhevet i selve teksten. Henvisning til kjernereferanser finner man i litteraturlisten, der de også er kommentert. Dette er pedagogisk lagt opp for leseren. Komplett litteraturliste samt ekstramateriale og enkelte videosnutter ligger som elektronisk tilleggsstoff - kjekt når man er på nett, men ikke tilgjengelig ellers.

Denne boken kan gjerne ses på som et nødvendig kjernepensum for alle kirurger og som et tillegg til en av de subspesialiserte bøkene om man ikke ønsker å investere i hele serien. Boken anbefales.

Publisert: 25. februar 2019. Tidsskr Nor Legeforen. DOI: 10.4045/tidsskr.18.0921

(C) Tidsskrift for Den norske legeforening 2020. Lastet ned fra tidsskriftet.no 